ISSN 1997-5902

\title{
A survey of plant-parasitic nematodes of yam farms in Awka-North local government area, Anambra state, Nigeria.
}

\author{
Duru Vincent, C. ${ }^{1}$, *Nwankwo, Edith N. ${ }^{1}$, Ogbonna, Confidence U. ${ }^{2}$, Onyido, A. E. ${ }^{1}$ and Adewuyi, $0 .{ }^{3}$ \\ ${ }^{1}$ Department of Parasitology and Entomology, Nnamdi Azikiwe University, Awka, Anambra State, Nigeria. ${ }^{2}$ \\ Department of Biology, Federal University Ndufu Alike lkwo, Ebonyi State ${ }^{3}$ Nematology Unit, International Institute of \\ Tropical Agriculture, Ibadan, Oyo State. \\ *Corresponding Author: Nwankwo, Edith N., chikanny@yahoo.com, +234 08039213567
}

Original submitted in on 26 th June 2015. Published online at www.m.elewa.org on 30 th November 2015 http://dx.doi.org/10.4314/jab.v95i1.4

\begin{abstract}
Objective: Soil-inhabiting plant parasitic nematodes of yam were investigated in yam fields in Awka-North Local Government Area of Anambra state, Nigeria.

Methodology and Results: Three farmlands each were randomly selected for sampling from the seven communities that make up the study area. Five yam plants were also randomly selected from each farm for sampling. Soil samples around the roots of each plant were collected using a hand trowel at a depth of 15$30 \mathrm{~cm}$. The relative percentage composition of nematodes in soils and yam tubers from each of the sampled communities (in $10 \mathrm{~mL}$ of extract suspension) was determined at the International Institute of Tropical Agriculture (IITA), Ibadan. The results showed that Pratylenchus sp. 140 (40.60\%) were the most prevalent species in the soil samples followed by Meloidogyne sp. 95 (27.54\%), Scutellonema sp. 50 (14.50\%), Helicotylenchus spp. 25 (7.25\%), Criconema sp. 20 (5.80\%), Radopholus sp. $10(2.90 \%)$ and cysts of Heterodera sp. being the least prevalent with prevalence rate of $5(1.45 \%)$. Similarly, out of the 180 plant parasitic nematodes recovered from the yam tubers, 130 (72.22\%) were Pratylenchus spp., 40 $(22.24 \%)$ were Scutellonema spp., 5 each $(2.78 \%)$ were Meloidogyne spp. and Radopholus spp. respectively. However, Helicotylenchus spp., Criconema spp. and cyst nematodes were not encountered in yam tuber samples. Amansea and Isuaniocha had the highest level of both soil and yam parasitic nematode infestation, although difference with respect to percentage composition of nematodes in the samples and the communities were not significantly different $(P>0.05)$. However, there was a significant difference $(P<0.05)$ between the number of nematode genera encountered in the soil and tuber samples.

Conclusion and application of results: The presence of these parasitic nematodes in the study area suggests that they can be important pathogens of yams although their presence has usually been neglected. The presence of these plant parasitic nematodes could constitute serious impediments to the growth and yield of yams in Awka-North L.G.A.
\end{abstract}

Key Words: Soil nematodes, Meloidogyne, Helicotylenchus, Dioscorea spp. 


\section{INTRODUCTION}

Yam (Dioscorea spp.) is an annual or perennial tuber-bearing and climbing plant that grows for 612 months depending on the cultivar, ecology and soil properties in the production area (NRCRI, 1998). It belongs to the genus Dioscorea and family Dioscoreaceae. There are over 600 species out of which 6 are economically important in terms of food and medicine (IITA, 2009). Though it originated in South-East Asia, it is cultivated mostly in West Africa where approximately $95 \%$ of world annual production (37 million tonnes) is grown (FAO, 2004). Yam is grown on 5 million hectares in about 47 countries of the world with Nigeria as the leading world producer (FAO, 2005; IITA, 2009). In $2005,48.7$ million tons of yams were produced in the world and $97 \%$ of these were in Sub-Saharan Africa, which accounts for $70 \%$ of world production grown on 2.83 million hectares of land (CGIAR, 2009 and IITA, 2009). Food and Agricultural Organisation (FAO, 1985) reported that Nigeria produced 18.3 million tonnes of yam, representing $73.8 \%$ of total yam production in Africa. According to their year 2008 figures, yam production in Nigeria has nearly doubled since 1985 with Nigeria producing 35.017 million tonnes, value equivalent to US\$ 5.654 billion. In addition, International Institute of Tropical Agriculture (IITA, 2011) reported that Nigeria accounted for about $70 \%$ of the world production amounting to 17 million tonnes from land area of $2,837,000$ hectares. It is a tropical tuber crop grown as a source of carbohydrate but also for use in ceremonial activities (Mudiope et al., 2007). Yam serves as staple food in many tropical and sub-tropical countries of the world and in Nigeria the principal source of carbohydrate. In Nigeria also, it is one of the principal tuber crops in the nation's economy in

\section{MATERIALS AND METHODS}

Study Area: Awka-North Local Government Area is located in the central senatorial zone of the geopolitical arrangement of Anambra State. It is one of the twentyone Local Government Areas that make up the State. It is comprised of ten different communities with Achalla the headquarters. Other communities are Amansea, Amanuke, Ebenebe, Awba-ofemili, Isuaniocha, Mgbakwu, Ugbene, Ugbenu and Urum. The study area terms of land under cultivation, in the volume and value of production (Bamire and Amujoyegbe, 2005). The crop is also used for cultural events including marriages and annual festivals especially in the South-Eastern part of the country. Among the various constraints to yam production are nematode pests, which are of significant importance (Bridge et al., 2005). Plant-parasitic nematodes are microscopic roundworms that are widely distributed and persist as soil plant pest for indefinite period (Obuezie and Ikpeze, 2012). A large number of plant parasitic nematodes associated with yam cultivation have been reported from various yam-producing areas of the world. In West Africa, the yam nematode, Scutellonema bradys, is a major causal agent of dry rot (Coyne et al., 2006) while in Central America, Pratylenchus sp. causes similar damage to that of S. bradys (Acosta and Ayala, 1976). Meloidogyne sp. can also cause in field and postharvest losses to yam (Bridge et al., 2005). In Nigeria, a host of plant parasitic nematodes were encountered from both root and soil samples from Edo, Ekiti and Oyo states. Scutellonema sp., Pratylenchus sp. and Meloidogyne sp. were most widely distributed in both samples from the three states (Adegbite et al., 2006). Presently, there is a dearth of published information on parasitic nematodes of yam in Anambra State, Southeastern part of Nigeria where yam is cultivated and used in large quantities. Against this background, the present study therefore was undertaken to establish the species and prevalence rate of plant parasitic nematodes causing damage to yams in farms in Awka North Local Government Area of Anambra state, Nigeria.

was within the tropical rainforest biome of Nigeria. Two seasons, dry and wet operate within the study area. The dry season usually runs from November to March while the wet season runs from April to October. The annual rainfall ranges from 2,000 to $3,000 \mathrm{~mm}$. Occupation of the people include agriculture, trading and civil service. Fertility of their soil supports the cropping of yams, cocoyam, maize and vegetables. 

local government area, Anambra state, Nigeria.

Some communities like Achalla, Awba-ofemili and Ebenebe cultivate rice as well. Many homesteads in addition to crop cultivation keep domestic livestock such as chicken, goats and sheep.

Sampling techniques for nematodes of yam: Three farmlands each were randomly selected for sampling from the seven communities that make up the study area namely; Achalla, Amansea, Amanuke, Ebenebe, Mgbakwu, Isuaniocha and Urum. Five yam plants were also randomly selected from each farm for sampling. Soil samples around the roots of each plant were collected using a hand trowel at a depth of $15-30 \mathrm{~cm}$ as recommended by Coyne et al. (2009). Samples of whole yam tubers were collected from the farmers. For each yam tuber collected, the level of damage was scored as recommended by Coyne et al. (2009).

Nematode Extraction and Identification: Samples of both soil and whole yam tuber from each farm were sealed in black polythene bags and placed in a cooler to protect them from the heat of the sun. The samples were properly labelled and taken to the International Institute of Tropical Agriculture (IITA), Ibadan Nematology laboratory for extraction and identification of the parasitic nematodes.

Extraction of nematodes from the soil samples: The extraction of plant parasitic nematodes from the soil sample was carried out using the extraction tray method, which is the modified Baerman's funnel method (Ravichandra, 2012). Each soil sample was thoroughly mixed and using a coarse sieve, debris and stones were removed by passing the soil through the sieve into a plastic plate. A sub-sample of $100 \mathrm{~mL}$ of soil was removed using a calibrated beaker. The extraction paper was placed in a plastic sieve that was subsequently placed on a plastic plate. The base of the

\section{RESULTS AND DISCUSSIONS}

The results of the present study showed that seven different genera of plant parasitic nematodes were identified in the soil and yam tubers collected from the seven communities. Identification was done at the International Institute of Tropical Agriculture (IITA), Ibadan, Headquarters. The nematodes identified were Meloidogyne spp.; Pratylenchus spp.; Radopholus spp., Helicotylenchus spp., Scutellonema spp., Criconema spp. and cyst nematodes (Heterodera sp.) (Tables 1 and 2).The percentage composition of nematodes in soils from each of the sampled communities as shown in Table 1 indicated that Pratylenchus sp. With population of $140(40.60 \%)$ were the most prevalent followed by Meloidogyne sp. 95 (27.54\%), while the least prevalent was the cysts of Heterodera $s p$. This sieve was fully covered by the extraction paper, and then the apparatus was labelled. The soil sample $(100 \mathrm{~mL})$ was placed on the extraction paper in the sieve. Water $(150 \mathrm{~mL})$ was initially added to the extraction plates between the edges of the sieve and the sides of the plate, ensuring that water was not poured onto the extraction paper or the soil. The set up was left to stand for 48hours. This was repeated for each sample from each farm from the seven communities involved. Nematodes were expected to move from the soil sample through the paper into the water below, resting on the plate. After the extraction period, excess water from the sieve was drained into the plate. The soil and the paper were then disposed and water from the plates emptied into labelled beakers. However, during the counting and identification, the volume of the water was reduced by gently pouring off through a $20 \mu \mathrm{m}$ sieve. Then $10 \mathrm{~mL}$ of the extract suspension were eventually viewed for presence of nematodes using Compound microscope.

Extraction of nematodes from samples of yam tuber: Yam tubers from each farm were carefully peeled with a kitchen knife below the surface. The tuber peels were chopped finely with the knife, further blended with an electric blender and then placed in labelled plates. All chopped tuber peels from each farm in each of the communities were properly labelled and kept separately according to communities where they were collected. Subsequently, sub-samples of $5 \mathrm{~g}$ each of the chopped tuber peels were weighed onto the extraction paper in the labelled sieve and placed on a plate. $100 \mathrm{~mL}$ of water was added to the extraction plates and left to stand for 24 hours. Then, $10 \mathrm{ml}$ of the extract suspension were eventually viewed for presence of nematodes using Compound microscope.

had population of $5(1.45 \%)$ (Table 1). Similarly, out of the four genera of the parasitic nematode recovered from the yam tubers, which are; Pratylenchus spp., Meloidogyne spp., Scutellonema spp., and Radopholus spp. The result showed that Pratylenchus spp. also recorded the highest prevalence of $130(72.22 \%)$ while Meloidogyne and Radopholus spp. recorded the least prevalence of $5(2.78 \%)$ respectively. The analysis of variance (ANOVA) showed that there was a significant difference $(P<0.05)$ in the numbers of the different genera of nematodes recovered both from the soil and yam tubers. The mean separation of the numbers of nematodes obtained from the soil showed that Pratylenchus $s p$. was significantly higher than all other nematodes except Meloidogyne sp. while in that of the 
nematodes from the yam tubers, Pratylenchus species was significantly higher than all the other genera of nematodes recovered. The result also showed that of the soil sampled from the seven communities, Amansea (Ams) recorded the highest number of parasitic nematodes of 110 (31.88\%) followed by Isuaniocha (Isu)and Amanuke (Amn) recording 55 $(15.94 \%)$ respectively while the least number of parasitic nematode was recorded in Urum (Uru) community $(15(4.35 \%))$ (Table 1$)$. Also of the yam sampled from the seven communities, Amansea recorded the highest number of nematodes of 45
$(25.00 \%)$ followed by Amanuke and Ebenebe with 35 $(19.44 \%)$ and $30(16.67 \%)$ respectively while the least $10(5.56 \%)$ was recorded in Mgbakwu (Table 2). Considering the infection rate, the result showed that Amansea and Isuaniocha recorded the highest infection of $100 \%$ of all soils and yam tubers collected from the farms from both communities (Figures 1 and 2), although the ANOVA showed that there was no significant difference $(P>0.05)$ in the number of parasitic nematodes obtained from the different communities (Tables 1 and 2). 
Duru et al. J. Appl. Biosci. 2015 A survey of plant-parasitic nematodes of yam farms in Awka-North local government area, Anambra state, Nigeria.

Table 1: Number and percentage composition of nematodes (in $10 \mathrm{~mL}$ of extract) found in soils from each of the sampled communities

\begin{tabular}{|c|c|c|c|c|c|c|c|c|c|}
\hline Communities & $\begin{array}{l}\text { Melo } \\
\text { No (\%) }\end{array}$ & $\begin{array}{l}\text { Praty } \\
\text { No }(\%)\end{array}$ & $\begin{array}{l}\text { Rado } \\
\text { No }(\%)\end{array}$ & $\begin{array}{l}\text { Helico } \\
\text { No }(\%)\end{array}$ & $\begin{array}{l}\text { Scut } \\
\text { No }(\%)\end{array}$ & $\begin{array}{l}\text { Crico } \\
\text { No }(\%)\end{array}$ & $\begin{array}{l}\text { Cyst } \\
\text { No (\%) }\end{array}$ & $\begin{array}{l}\text { Total } \\
\text { No }(\%)\end{array}$ & Mean \pm SE \\
\hline Ach & $10(10.52)$ & $15(10.71)$ & $0(0.00)$ & $0(0.00)$ & $0(0.00)$ & $0(0.00)$ & $0(0.00)$ & $25(7.25)$ & $3.60 \pm 2.37$ \\
\hline Ams & $45(47.37)$ & $15(10.71)$ & $10(100)$ & $5(20.00)$ & $15(30.00)$ & $20(100)$ & $0(0.00)$ & $110(31.88)$ & $15.7 \pm 5.50$ \\
\hline Amn & $15(15.79)$ & $25(17.86)$ & $0(0.00)$ & $0(0.00)$ & $15(30.00)$ & $0(0.00)$ & $0(0.00)$ & 55 (15.94) & $7.90 \pm 3.91$ \\
\hline Ebe & $25(26.32)$ & $15(10.71)$ & $0(0.00)$ & $5(20.00)$ & $0(0.00)$ & $0(0.00)$ & $0(0.00)$ & $45(13.04)$ & $6.40 \pm 3.73$ \\
\hline Isu & $0(0.00)$ & $25(17.86)$ & $0(0.00)$ & $15(60.00)$ & $10(20.00)$ & $0(0.00)$ & $5(100)$ & 55 (15.94) & $7.90 \pm 3.60$ \\
\hline Mgb & $0(0.00)$ & 30 (21.43) & $0(0.00)$ & $0(0.00)$ & $10(20.00)$ & $0(0.00)$ & $0(0.00)$ & 40 (11.59) & $5.70 \pm 4.29$ \\
\hline Uru & $0(0.00)$ & $15(10.71)$ & $0(0.00)$ & $0(0.00)$ & $0(0.00)$ & $0(0.00)$ & $0(0.00)$ & $15(4.35)$ & $2.10 \pm 2.14$ \\
\hline $\begin{array}{l}\text { TOTAL } \\
\text { Mean } \pm S E\end{array}$ & $\begin{array}{l}95(27.54) \\
13.6 \pm 6.34\end{array}$ & $\begin{array}{l}140(40.58) \\
20.0 \pm 2.44\end{array}$ & $\begin{array}{l}10(2.90) \\
1.40 \pm 1.43\end{array}$ & $\begin{array}{l}25(7.25) \\
3.60 \pm 2.10\end{array}$ & $\begin{array}{l}50(14.49) \\
7.10 \pm 2.64\end{array}$ & $\begin{array}{l}20(5.79) \\
2.90 \pm 2.86\end{array}$ & $\begin{array}{l}5(1.45) \\
0.70 \pm 0.74\end{array}$ & $345(100)$ & \\
\hline
\end{tabular}

*community--- $P=0.268$. Nematode--- $P<0.001$, LSD $=8.91$

Table 2: Number and percentage composition of nematodes (in $10 \mathrm{~mL}$ of extract) found in samples of yam tubers from each community.

\begin{tabular}{|c|c|c|c|c|c|c|}
\hline Communities & $\begin{array}{l}\text { Melo } \\
\text { No (\%) }\end{array}$ & $\begin{array}{l}\text { Praty } \\
\text { No (\%) }\end{array}$ & $\begin{array}{l}\text { Rado } \\
\text { No (\%) }\end{array}$ & $\begin{array}{l}\text { Scut } \\
\text { No (\%) }\end{array}$ & $\begin{array}{l}\text { Total } \\
\text { No }(\%)\end{array}$ & Mean $\pm S E$ \\
\hline Ach & $0(0.00)$ & $10(7.69)$ & $0(0.00)$ & $10(25.00)$ & $20(11.11)$ & $5.0 \pm 2.89$ \\
\hline Ams & $5(100)$ & $35(26.92)$ & $5(100)$ & $0(0.00)$ & $45(25.00)$ & $11.2 \pm 8.00$ \\
\hline Amn & $0(0.00)$ & $35(26.92)$ & $0(0.00)$ & $0(0.00)$ & 35 (19.44) & $8.8 \pm 8.75$ \\
\hline Ebe & $0(0.00)$ & $25(19.23)$ & $0(0.00)$ & $5(12.50)$ & 30 (16.67) & $7.5 \pm 5.95$ \\
\hline Isu & $0(0.00)$ & $15(11.54)$ & $0(0.00)$ & $10(25.00)$ & 25 (13.89) & $3.8 \pm 3.75$ \\
\hline Mgb & $0(0.00)$ & $5(3.85)$ & $0(0.00)$ & $5(12.50)$ & $10(5.56)$ & $2.5 \pm 1.44$ \\
\hline Uru & $0(0.00)$ & $5(3.85)$ & $0(0.00)$ & $10(25.00)$ & $15(8.33)$ & $3.8 \pm 2.39$ \\
\hline Total & $5(2.78)$ & $130(72.22)$ & $5(2.78)$ & $40(22.22)$ & $180(100)$ & \\
\hline Mean $\pm S E$ & $0.7 \pm 0.71$ & $18.6 \pm 4.97$ & $0.7 \pm 0.71$ & $5.7 \pm 1.70$ & & \\
\hline
\end{tabular}

${ }^{*}$ Community---P=0.926.Nematode--- $P<0.01$, LSD=7.80 
This study has shown that plant parasitic nematode infection of agricultural fields could constitute an important economic problem in yam production in Awka-North L.G.A. Seven genera of plant parasitic nematodes were encountered in soil and root samples collected from the sampled area and these are; Meloidogyne sp., Pratylenchus sp., Scutellonema sp., Radopholus sp., Helicotylenchus sp., Criconema sp. and cyst nematodes (Heterodera $s p$.). This is in line with the study carried out by Adegbite et al. (2008) who reported the same genera of parasitic nematodes their study area. The presence of these parasitic nematodes suggests they can be important pathogens of yams although their economic importance has been usually undermined in these areas. The reason for the number of positive samples encountered in these communities could be continuous cultivation of the farms with yam, which provides these parasites with constant nutrition (Windham, 1998; Adegbite et al. 2005). The highest number of plant parasitic nematodes recorded in Amansea and Isuaniocha might be the reason for the high rate of damage to yam tubers observed in these communities as compared to other communities. Plant parasitic nematode damage is an important factor in tuber quality reduction and yield loss in yam both in the field and in storage. Yams are vulnerable to nematode damage as they reduce the yield and quality of the tubers because of root galling caused by Meloidogyne sp., root lesions caused by Pratylenchus sp. and dry and soft rots caused by Scutellonema sp. The presence of these plant parasitic nematodes could constitute serious impediments to the growth and yield of yams in Awka-North L.G.A. Enlightenment programme for the yam farmers should therefore be embarked upon by the Local Government and State Agricultural Development Programmes in the zone, to inform the farmers of the presence of plant parasitic nematodes in their farms and attendant implications.

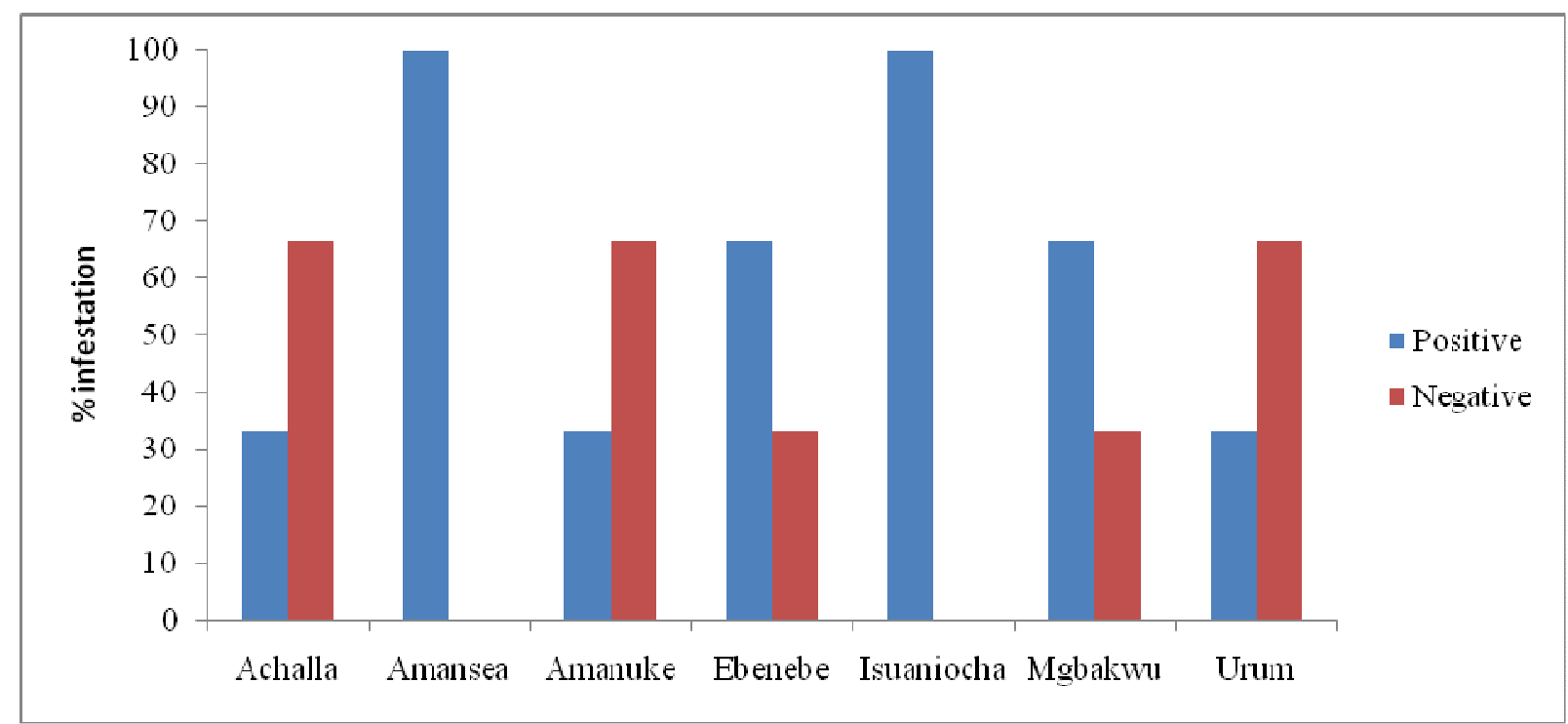

Figure 1: Percentage infection of soil collected from the seven communities in Awka-North Local Government of Anambra State. 


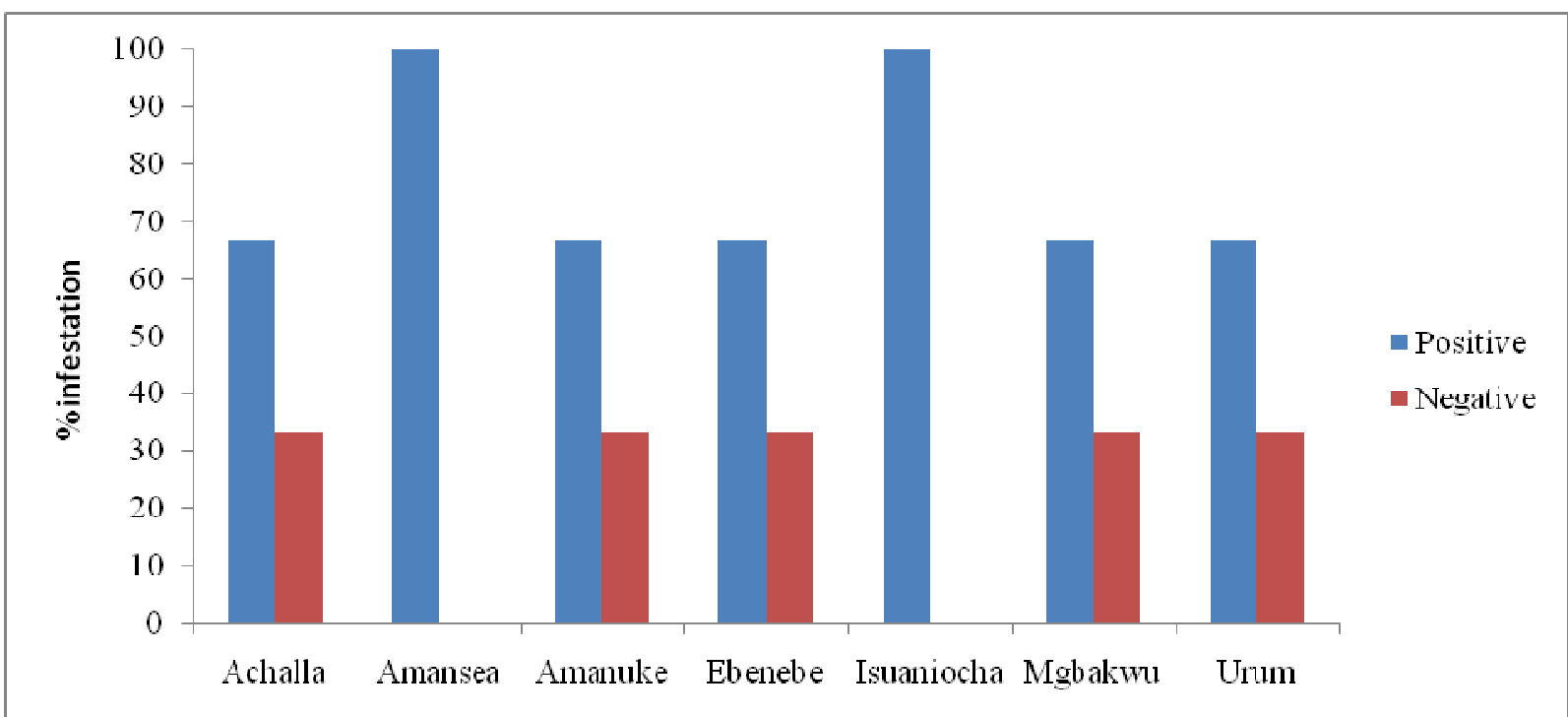

Figure 2: Percentage infection of yam tuber samples collected from seven communities in Awka-North Local Government of Anambra State.

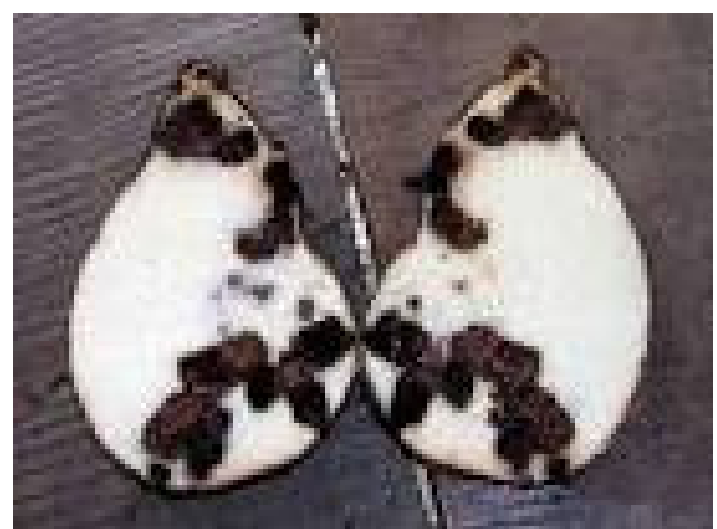

Figure 3: Picture of a yam damaged by nematode infections

\section{REFERENCES}

Acosta, N. and Ayala, A. (1976).Effects of Pratylenchus coffeae and Scutellonema bradys alone and in combination on Guinea yam (D. rotundata). Journal of Nematology, 8: 315-317.

Adegbite, A. A., Adesiyan, S. O. Agbaje, G. O. and Omoloye, A. A. (2005). Host Suitability of Crops under Yam Intercrop to Root-knot Nematode (Meloidogyne incognita Race 2) in South-Western Nigeria. Journal of Agricultural and Rural Development in Tropics and Subtropics, 106 (2): 113-118.

Adegbite, A. A., Saka J.O., Agbaje G.O., Owolade O. F., Olaifa, G.O., Lawal, A., and Ojo, S.T. (2006). Survey of plant parasitic nematodes associated with yams in Edo, Ekiti and Oyo

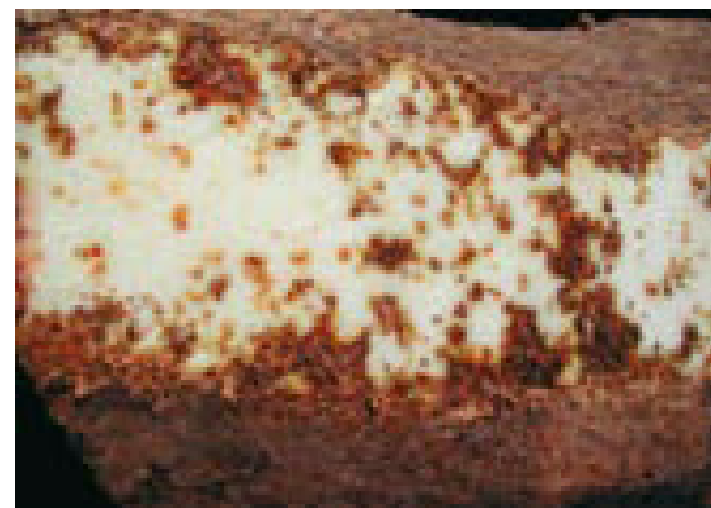

Figure 4: picture of internal lesion and necrosis caused by nematodes on a yam.

states of Nigeria. African Journal of Agricultural Research, 1 (4): 125-130.

Adegbite, A. A., Saka J.O., Agbaje G.O. and Osuloye F. O. (2008). Survey of Plant-parasitic Nematodes Associated with yams in Ogun and Osun states of Nigeria. Journal of Plant Protection Research, 48 (4): 421-428.

Bamire, A. S., Amujoyegbe B. J. (2005). Economic analysis of land improvement techniques in small-holder yam-based production systems in the Agro-ecological zones of south western Nigeria. Journal of Human Ecology, 18 (1): 112.

Bridge, J., Coyne D. and Kwoseh C.K. (2005). Nematode parasites of Tropical Root and 
Tuber Crops. In: Plant Parasitic Nematodes in Subtropical and Tropical Agriculture $2^{\text {nd }}$ edition. Luc M., Sikora R. and Bridge, J. (eds.) 221-258.

CGIAR (2009). www.cgiar.org. Date accessed $25^{\text {th }}$ September 2014.

Coyne, D. L, Tchabi A., Baimey H., Labushagne N., and Rotifa I. (2006).Distribution and prevalence of nematodes (Scutellonema bradys and Meloidogyne sp.) on marketed yam (Dioscorea sp.) in West Africa. Journal of Field Crop Research, 96: 142-150.

Coyne, D.L., Nicol, J.M. and Claudius-Cole, B. (2009).Practical plant nematology: a field and laboratory guide. SP-IPM Secretariat, International Institute of Tropical Agriculture (IITA), Cotonou, Benin.Pg: 31-42.

Food and Agricultural Organisation (FAO) (1985). www.faostat.org/1985faostat.Date accessed 25th September 2014.

Food and Agricultural Organisation (FAO) (2004). www.faostat.org/2004faostat.Date accessed 25th September 2014.

Food and Agricultural Organisation (FAO) (2005). www.faostat.org/2005faostat.Date accessed 25th September 2014.
International Institute of Tropical Agriculture (IITA) (2009). http:/www.itta.org.Date accessed: $1^{\text {st }}$ August, 2014.

Mudiope, J., Speijer P.R., Coyne D.L, Maslen R. N., and Adipala E. (2007).Nematode distribution and damage to yam in central and Eastern Uganda. African Crop Science Journal, 15 (2): 93-99.

National Root Crop Research Institute (NRCRI) (1998). Yam improvement studies. Annual Report of National Root Crops Research Institute, Umudike.

Obuezie, C. B. and 0.O. Ikpeze. (2012). Parasitic Nematodes of maize in farms at Oba, Idemili south Local Government Area of Anambra state Nigeria. Journal of Occupational Safety and Environmental Health, (1): 73-78.

Ravichandra, N. G. (2010). Methods and techniques in plant nematology. PHI Learning Private Ltd Publication, Pp 35-37.

Windham, G.L. (1998). Corn in: plant and Nematode Interactions. Agronomy Monograph no. 36.American Society of Agronomy, Madison, WI, 335-357. 